\title{
Analisis Komparatif Efektivitas dan Kontribusi Pajak Reklame Kabupaten Kebumen dan Kabupaten Purworejo Tahun 2017-2019
}

Effectiveness of

Regional

Advertisement Tax

\author{
Akfila Wulandari ${ }^{1}$, Arya Samudra Mahardhika ${ }^{2}$ \\ ${ }^{1,2}$ Program Studi Akuntansi, Sekolah Tinggi Ilmu Ekonomi Putra Bangsa, Kebumen, \\ E-Mail : akfilawulandari99@gmail.com
}

Submitted: DESEMBER 2020

\begin{abstract}
The study aimed to determine the comparative (comparison) effectiveness and contribution of advertisement tax in Kebumen Regency and Purworejo Regency in 2017-2019. The research method used was quantitative descriptive by using secondary data obtained from the Directorate General of Balance and Finance, Ministry of Finance (DJPK) in the form of billboard tax target data, billboard tax realization, and realization of local revenue (PAD). The analysis used in this study using the ratio of effectiveness and contribution. The results of the research on advertisement tax in Kebumen Regency and Purworejo Regency in 2017-2019 showed that the effectiveness level of the advertisement tax was included in the very effective criteria with an average of 165,07\% Kebumen Regency and 161,67\% of Purworejo Regency while the contribution of advertisement tax to Regional Original Income (PAD) has the criteria of relatively not contributing with an average of 0,16\% Kebumen Regency and 0,20\% Purworejo Regency. The comparison of the level of effectiveness shows that Kebumen Regency has a superior level of effectiveness than Purworejo Regency. The large comparison of contributions shows that Purworejo Regency is superior in terms of contribution than Kebumen Regency.
\end{abstract}

Keywords:Advertising Tax, Regional Original Income (PAD), Effectiveness, Contribution, Compatarification (Comparison)

\begin{abstract}
ABSTRAK
Penelitian ini bertujuan untuk mengetahui perbandingan (perbandingan) efektivitas dan kontribusi pajak reklame di Kabupaten Kebumen dan Kabupaten Purworejo Tahun 2017-2019. Metode penelitian yang digunakan adalah deskriptif kuantitatif dengan menggunakan data sekunder yang diperoleh dari Direktorat Jenderal Perimbangan dan Keuangan Kementerian Keuangan (DJPK) berupa data target pajak reklame, realisasi pajak reklame, dan realisasi pendapatan asli daerah (PAD). Analisis yang digunakan dalam penelitian ini menggunakan rasio efektivitas dan kontribusi. Hasil penelitian pajak reklame di Kabupaten Kebumen dan Kabupaten Purworejo tahun 2017-2019 menunjukkan tingkat efektivitas pajak reklame termasuk dalam kriteria sangat efektif dengan rata-rata 165,07\% Kabupaten Kebumen dan 161,67\% Kabupaten Purworejo sedangkan kontribusi pajak reklame terhadap Pendapatan Asli Daerah (PAD) memiliki kriteria relatif tidak memberikan kontribusi dengan rata-rata 0,16\% Kabupaten Kebumen dan 0,20\% Kabupaten Purworejo. Perbandingan tingkat efektivitas menunjukkan bahwa Kabupaten Kebumen memiliki tingkat efektivitas yang lebih unggul dibandingkan Kabupaten Purworejo. Perbandingan kontribusi yang besar menunjukkan bahwa Kabupaten Purworejo lebih unggul dalam hal kontribusi dibandingkan Kabupaten Kebumen.
\end{abstract}

Kata Kunci: pajak reklame, pendapatan asli daerah, efektivitas, kontribusi
Accepted: JUNI 2021

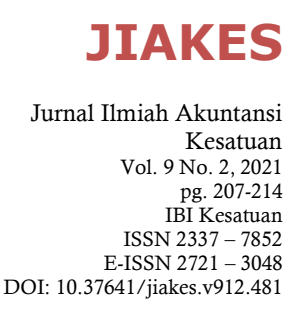


Effectiveness of

Regional

Advertisement Tax

\section{PENDAHULUAN}

Negara Kesatuan Republik Indonesia merupakan negara yang menganut sistem otonomi daerah dalam menjalankan pemerintahannya. Otonomi daerah merupakan salah satu wujud reformasi terhadap penyelenggaraan pemerintah daerah provinsi/kabupaten/kota demi mengantisipasi berbagai tuntutan perubahan ketatanegaraan baik secara sosial maupun politik yang berasal dari dalam negeri maupun luar negeri. Menurut Undang-undang Nomor 32 Tahun 2004 tentang Pemerintahaan Daerah, "Otonomi daerah merupakan hak, wewenang, dan kewajiban daerah untuk mengatur dan mengurus sendiri urusan pemerintah dan kepentingan masyarakat setempat sesuai dengan peraturan perundang-undangan yang berlaku." Otonomi daerah menuntut tiap-tiap daerah untuk mempersiapkan sumber daya manusia yang baik, sumber keuangan yang cukup serta sarana dan prasarana yang memadi dalam pelaksanaannya. Faktor keuangan merupakan aspek utama yang dititikberatkan dalam pelaksanaan otonomi daerah karena pada hakikatnya otpnomi daerah menuntut usaha pemerintah daerah untuk secara mandiri membiayai pengeluaran-pengeluarannya, sehubungan dengan program-program yang dilaksanakan oleh suatu daerah (Ariyanti $e l$ al, 2020: 49).

Pendapatan Asli Daerah (PAD) juga merupakan sumber pendapatan daerah yang secara bebas dapat digunakan oleh masing-masing daerah untuk menyelenggarakan pemerintahan dan pembangunan daerah. Masalah Pendapatan Asli Daerah (PAD) merupakan kendala utama bagi daerah dalam menyelenggarakan pelayanan bagi masyarakat, hal ini disebabkan proporsi Pendapatan Asli Daerah (PAD) relatif masih kecil apabila dibandingkan dengan proporsi bantuan pemerintah pusat (Lintong et al, 2015: 422). Untuk mengurangi ketergantungan kepada pemerintah pusat, pemerintah daerah perlu berusaha meningkatkan pendapatan asli daerah dengan mengoptimalkan pemungutan pajak daerah.

Pemerintah telah melakukan beberapa kebijakan perpajakan daerah dalam rangka meningkatkan kemampuan keuangan daerah supaya daerah dapat melaksanakan otonomi daerah. Diantaranya yaitu, dengan menetapkan Undang-Undang Nomor 28 Tahun 2009 tentang Pajak Daerah dan Retribusi Daerah adalah iuran yang dapat dipaksa oleh wajib membayarnya berdasarkan peraturan perundang-undangan yang berlaku tanpa imbalan langsung yang seimbang, dan yang digunakan untuk membiayai oenyelengaraan pemerintah daerah.

Salah satu jenis pajak daerah yang diperkenankan untuk dilakukan pemungutan pajaknya oleh pemerintah kabupaten/kota adalah pajak reklame. Menurut Undangundang Republik Indonesia Nomor 28 Tahun 2009 tentang Pajak Daerah dan Retribusi Daerah Pasal 1 ayat (27), pajak reklame, "Pajak reklame adalah benda, alat, perbuatan, atau media yang bentuk dan corak ragamnya dirancang untuk tujuan komersial memperkenalkan, menganjurkan, mempromosika, atau untuk menarik perhatian umum terhadap barang, jas, orang, atau bandan, yang dapat dilihat, dibaca, didengar, dirasakan, dan/ dinikmati oleh umum."

Pajak reklame adalah salah satu sumber pendapatan daerah. Penerapan iklan pada reklame menjadi media yang cukup diminati, salah satunya di Kabupaten Kebumen dan Kabupaten Purworejo. Reklame juga difungsikan untuk menarik perhatian umum terhadap sesuatu yang diperlihatkan atau diiklankan. Pengembangan reklame tentunya perlu dikelola secara terpadu dengan memperhatikan aspek pemerintahan yang baik, desentralisasi, sumber daya manusia dan pemberdayaan masyarakat lokal dalam rangka mengembangkan reklame atau periklanan.

Kebumen dan Purworejo selain merupakan pusat pemerintahan kabupaten juga merupakan pusat kegiatan ekonomi bagi masyarakat disekitar, oleh karena itu, tidak sedikit perseorangan atau badan usaha yang menggunakan reklame sebagai alat untuk mempromosikan usahanya. Pajak reklame merupakan pajak dengan tarif yang cukup tinggi dibandingkan dengan pajak yang lain yaitu sebesar $25 \%$. Sehingga penerimaan pajak reklame tentunya akan berkontribusi terhadap perolehan Pendapatan Asli Daerah (PAD) di Kabupaten Kebumen dan Kabupaten Purworejo. 
Sehingga dalam penelitian ini peneliti akan mengkaji penerimaan pajak reklame di Kabupaten Kebumen dan Kabupaten Purworejo. Peneliti memilih Kabupaten Kebumen dan Kabupaten Purworejo karena kedua daerah tersebut sama-sama masuk dalam karesidenan kedu selain itu Kabupaten Kebumen dan Kabupaten Purworejo merupakan kabupaten yang sama-sama mengalami perkembangan terbukti dari data awal yang telah diperoleh dimana dua kabupaten tersebut pada tahun 2017 dan 2019 bisa melebihi target pajak yang telah ditetapkan dan pada tahun 2018 sama- sama tidak bisa mencapai target pajak reklame yang sudah ditentukan.

Berdasarkan uraian latar belakang maka rumusaan masalah dan tujuan penelitian adalah sebagai berikut:

a. Bagaimana efektivitas dan kontribusi pajak reklame terhadap Pendapatan Asli Daerah (PAD) Kabupaten Kebumen tahun 2017-2019?

b. Bagaimana efektivitas dan kontribusi pajak reklame terhadap Pendapatan Asli Daerah (PAD) Kabupaten Purworejo 2017-2019?

c. Bagaimana perbandingan efektivitas dan kontribusi pajak reklame di Kabupaten Kebumen dan Kabupaten Purworejo 2017-2019?

Alur penelitian dalam penelitian ini adalah sebagai berikut:

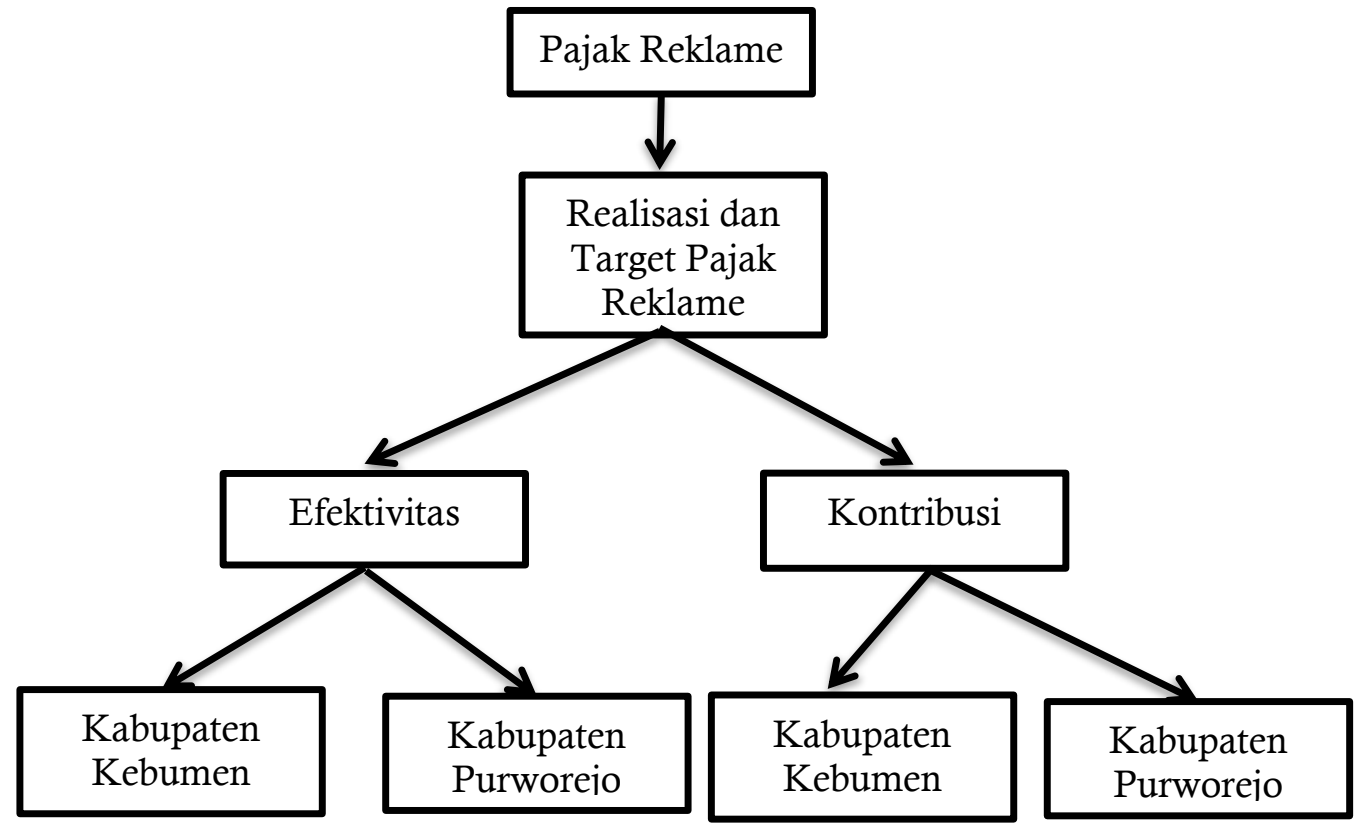

Gambar II.1 Alur Penelitian
Effectiveness of

Regional

Advertisement Tax

209

Keterangan:

1. Pajak reklame adalah biaya yang harus dibayar agar mendapatkan izin penyelenggaraan reklame.

2. Realisasi pajak reklame, sedangkan realisasi merupakan data yang diperoleh dari penerimaan pajak reklame selama periode tahun 2017-2019.

3. Efektivitas dan kontribusi terhadap Pendapatan Asli Daerah (PAD), efektivitas sendiri adalah pencapaian suatu target dan kontribusi terhadap Pendapatan Asli Daerah (PAD) adalah suatu sumbangan dari pajak reklame untuk Pendapatan Asli Daerah.

4. Perbandingan efektivitas dan kontribusi pajak reklame terhadap Pendapatan Asli Daerah di Kabupaten Kebumen dan Kabupaten Purworejo.

\section{METODE PENELITIAN}

Objek dalam penelitian ini yaitu target dan realisasi penerimaan pajak reklame serta realisasi penerimaan Pendapatan Asil Daerah (PAD) Kabupaten Kebumen dan Kabupaten Purworejo tahun 2017-2019. Sumber data yang digunakan dalam penelitian ini adalah data sekunder yang merupakan sumber data penelitian yang diperoleh peneliti secara tidak langsung melalui media perantara (diperoleh dan dicatat oleh pihak lain). 
Effectiveness of

Regional

Advertisement Tax

\section{0}

Data sekunder yang digunakan dalam penelitian ini adalah laporan penerimaan terget pajak reklame, laporan penerimaan realisasi pajak reklame dan laporan realisasi Pendapatan Asli Daerah Kabupaten Kebumen dan Kabupaten Purworejo Tahun 20172019. Sedangkan jenis data yang digunakan adalah kuantitatif, merupakan data yang berbrntuk angka-angka yang diperoleh dari hasil pengamatan dalam satu periode tertentu. Data kuantitatif dalam penelitian ini adalah laporan target pajak reklame, laporan realisasi pajak reklame dan laporan realisasi Pendapatan Asli Daerah Kabupaten Kebumen dan Kabupaten Purworejo tahun 2017-2019. Teknik pengumpulan data dalam penelitian ini adalah teknik documenter yang diunduh dari situs Direktorat Jenderal Perimbangan Keuangan (www.djpk.kemenku.go.id).

Metode analisis data yang digunakan yaitu deskriptif kuantitatif yaitu suatu metode pembahasan masalah yang sifatnya menggambarkan, menguraikan, membandingkan suatu data atau keadaan serta menerangkan suatu keadaan yang sedemikian rupa sehingga dapatlah kesimpulan.

1. Analisis efektivitas penerimaan pajak reklame dapat diukur menggunakan rumus sebagai berikut:

\begin{tabular}{|l}
$\begin{array}{l}\text { Efektivitas Penerimaan Pajak Reklame } \\
\text { Realisasi Penerimaan Pajak Reklame }\end{array}$ \\
Sumber: Atteng (2016: 50$)$
\end{tabular}

Efektivitas secara lebih rinci dapat diukur dengan menggunakan kriteria sebagai berikut:

\begin{tabular}{cc}
\hline Persentase & Kriteria \\
\hline$>100 \%$ & Sangat Efektif \\
$90 \%-100 \%$ & Efektif \\
$80 \%-89,9 \%$ & Cukup Efektif \\
$60 \%-79,9 \%$ & Kurang Efektif \\
$\leq 59,9 \%$ & Tidak Efektif \\
\hline
\end{tabular}

Sumber: Harumdhani (2012: 23)

2. Analisis kontribusi penerimaan pajak reklame terhadap Pendapatan Asli Derah (PAD) Kontribusi Pajak Reklame Terhadap Pendapatan Asli Daerah

Kontribusi Pajak Reklame Terhadap Pendapatan Asli Daerah

$$
=\frac{\text { Realisasi Penerimaan Pajak Reklame }}{\text { Target Penerimaan Pendapatan Asli Daerah }} \times 100 \%
$$

Sumber: Atteng (2016: 50)

Kontribusi secara lebih rinci dapat diukur dengan menggunakan kriteria sebagai berikut:

\begin{tabular}{cc}
\hline Persentase & Kriteria \\
\hline $0 \%-0,9 \%$ & Relatif tidak berkontribusi \\
$1 \%-1,9 \%$ & Kurang berkontribusi \\
$2 \%-2,9 \%$ & Cukup memiliki konteribusi \\
$3 \%-3,9 \%$ & Memiliki konteribusi \\
$>4 \%$ & Sangat tidak memiliki kontribusi \\
\hline
\end{tabular}

Sumber: Harumdhani (2016: 26)

3. Analisis perbandingan efektivitas dan kontribusi pajak reklame terhadap Pendapatan Asli Daerah (PAD). Perbandingan efektivitas dan kontribusi pajak reklame terhadap pendaptan asli daerah Kabupaten Kebumen dan Kabupaten Purworejo dapat diketahui dengan langkah-langkah sebagai berikut: 
a. Perbandingan dilakukan pada tahun 2017-2019 dengan cara membandingkan tahun sebelumnya dan tahun sesudahnya.

b. Perbandingan dilakukan di Kabupaten Kebumen dan Kabupaten Purworejo.

c. Perbandingan dilakukan dengan menghitung tingkat efektivitas daan kontribusi kemudian hasilnya diukur menggunakan interprestasi efektivitas dan kontribusi menurut Harumdhani (2016: 26).

\section{HASIL DAN PEMBAHASAN}

Analisis Efektivitas Penerimaan Pajak Reklame Kabupaten Kebumen 2017-2019

Tabel 1 Efektifitas Penerimaan Pajak Reklame Kabupaten Kebumen Tahun 2017-2019

\begin{tabular}{ccccc}
\hline $\begin{array}{c}\text { Tahun } \\
\text { Anggaran }\end{array}$ & $\begin{array}{c}\text { Target Pajak } \\
\text { Reklame }(\mathrm{Rp})\end{array}$ & $\begin{array}{c}\text { Realisasi Pajak } \\
\text { Reklame }(\mathrm{Rp})\end{array}$ & $\begin{array}{c}\text { Efektivitas } \\
(\%)\end{array}$ & Kriteria Efektivitas \\
\hline 2017 & $411.000 .000,00$ & $650.272 .185,00$ & $158,21 \%$ & Sangat Efektif \\
2018 & $600.000 .000,00$ & $316.508 .320,00$ & $52,75 \%$ & Tidak Efektif \\
2019 & $400.000 .000,00$ & $1.137 .116 .644,00$ & $284,27 \%$ & Sangat Efektif \\
\hline
\end{tabular}

Sumber: data diolah (2020)

Berdasarkan tabel 1 efektivitas penerimaan pajak reklame Kabupaten Kebumen pada tahun 2017 memiliki tingkat efektivitas 158,21\% yang berarti masuk dalam kriteria sangat efektiv, pada tahun 2018 memiliki tingkat efektivitas sebesar 52,75\% yang berarti masuk dalam kriteria tidak efektiv, pada tahun 2019 memiliki tingkat efektivitas sebesar 284,27\% yang berarti masuk dalam kriteria sangat memiliki efektivitas.

Analisis Efektivitas Penerimaan Pajak Reklame Kabupaten Purworejo 2017- 2019

Tabel 2 Efektifitas Penerimaan Pajak Reklame Kabupaten Purworejo 2017-2019

\begin{tabular}{ccccc}
\hline $\begin{array}{c}\text { Tahun } \\
\text { Anggaran }\end{array}$ & $\begin{array}{c}\text { Target Pajak } \\
\text { Reklame (Rp) }\end{array}$ & $\begin{array}{c}\text { Realisasi Pajak } \\
\text { Reklame (Rp) }\end{array}$ & $\begin{array}{c}\text { Efektivitas } \\
(\%)\end{array}$ & $\begin{array}{c}\text { Kriteria } \\
\text { Efektivitas }\end{array}$ \\
\hline 2017 & $520.000 .000,00$ & $541.951 .392,00$ & $104,22 \%$ & Sangat Efektif \\
2018 & $570.000 .000,00$ & $272.150 .831,00$ & $47,74 \%$ & Tidak Efektif \\
2019 & $223.070 .800,00$ & $745.196 .062,00$ & $334,06 \%$ & Sangat Efektif \\
\hline
\end{tabular}

Sumber: data diolah (2020)

Berdasarkan tabel 2 efektivitas penerimaan pajak reklame Kabupaten Purworejo pada tahun 2017 memiliki tingkat efektivitas 104,22\% yang berarti masuk dalam kriteria sangat efektiv, pada tahun 2018 memiliki tingkat efektivitas sebesar 47,74\% yang berarti masuk dalam kriteria tidak efektiv, pada tahun 2019 memiliki tingkat efektivitas sebesar 334,06\% yang berarti masuk dalam kriteria sangat memiliki efektivitas.

Analisis Kontribusi Penerimaan Pajak Reklame Terhadap Pendapatan Asli Daerah (PAD) Kabupaten Kebumen Tahun 2017-2019

Tabel 3 Kontribusi Penerimaan Pajak Reklame Terhadap Pendapatan Asli Daerah Kabupaten Kebumen Tahun 2017-2019

\begin{tabular}{ccccc}
\hline $\begin{array}{c}\text { Tahun } \\
\text { Anggaran }\end{array}$ & $\begin{array}{c}\text { Realisasi Pajak } \\
\text { Reklame (Rp) }\end{array}$ & $\begin{array}{c}\text { Realisasi PAD } \\
(\mathrm{Rp})\end{array}$ & $\begin{array}{c}\text { Persentase } \\
(\%)\end{array}$ & Kriteria Kontribusi \\
\hline 2017 & $650.272 .185,00$ & 443.608 .862 .461 & $0,14 \%$ & $\begin{array}{c}\text { Relatif tidak } \\
\text { berkontribusi } \\
\text { Relatif tidak } \\
\text { berkontribusi } \\
\text { Relatif tidak } \\
\text { berkontribusi }\end{array}$ \\
\hline
\end{tabular}

Sumber: data diolah (2020)

Berdasarkan tabel 3 kontribusi penerimaan pajak reklame terhadap Pendapatan Asli Daerah (PAD) Kabupaten Kebumen pada tahun 2017 memiliki presentase 0,14\% yang berarti masuk dalam kriteria relatif tidak berkontribusi, pada tahun 2018 memiliki presentase sebesar 0,089\% masuk dalam kriteria relatif tidak berkontribusi, pada tahun 2019 memiliki presentase sebesar $0,27 \%$ masuk dalam kriteria relatif tidak berkontribusi. 
Effectiveness of

Regional

Advertisement Tax
Analisis Kontribusi Penerimaan Pajak Reklame Terhadap Pendapatan Asli Daerah (PAD) Kabupaten Purworejo Tahun 2017-2019

Tabel 4 Kontribusi Penerimaan Pajak Reklame Terhadap Pendapatan Asli Daerah Kabupaten Purworejo Tahun 2017-2019

\begin{tabular}{|c|c|c|c|c|}
\hline $\begin{array}{c}\text { Tahun } \\
\text { Anggaran }\end{array}$ & $\begin{array}{c}\text { Realisasi Pajak } \\
\text { Reklame (Rp) }\end{array}$ & $\begin{array}{c}\text { Realisasi PAD } \\
\text { (Rp) }\end{array}$ & $\begin{array}{c}\text { Persentase } \\
(\%)\end{array}$ & $\begin{array}{c}\text { Kriteria } \\
\text { Kontribusi }\end{array}$ \\
\hline 2017 & $520.000 .000,00$ & 298.606 .494 .653 & $0,18 \%$ & $\begin{array}{l}\text { Relatif tidak } \\
\text { berkontribusi }\end{array}$ \\
\hline 2018 & $570.000 .000,00$ & 286.971 .590 .024 & $0,09 \%$ & $\begin{array}{l}\text { Relatif tidak } \\
\text { berkontribusi }\end{array}$ \\
\hline 2019 & $223.070 .800,00$ & 280.396 .155 .600 & $0,35 \%$ & $\begin{array}{l}\text { Relatif tidak } \\
\text { berkontribusi }\end{array}$ \\
\hline
\end{tabular}

Sumber: data diolah (2020)

Berdasarkan tabel 4 kontribusi penerimaan pajak reklame terhadap Pendapatan Asli Daerah (PAD) Kabupaten purworejo pada tahun 2017 memiliki presentase 0,18\% yang berarti masuk dalam kriteria relatif tidak berkontribusi, pada tahun 2018 memiliki presentase sebesar $0,09 \%$ masuk dalam kriteria relatif tidak berkontribusi, pada tahun 2019 memiliki presentase sebesar 0,35\% masuk dalam kriteria relatif tidak berkontribusi.

Analisis Perbandingan Tingkat Efetivitas Pajak Reklame Kabupaten Kebumen Dan Kabupaten Purworejo Tahun 2017-2019

Tabel 5. Perbandingan Tingkat Efektivitas Pajak Reklame di Kabupaten Kebumen dan Kabupaten Purworejo Tahun 2017-2019

\begin{tabular}{ccllc}
\hline Tahun & Kabupaten & Efektivitas & Kriteria Efektivitas & Rata-rata (\%) \\
\hline 2017 & \multirow{2}{*}{ Kebumen } & $158,21 \%$ & Sangat Efektif & \\
2018 & & $52,75 \%$ & Tidak Efektif & \multirow{2}{*}{$165,07 \%$} \\
2019 & & $284,27 \%$ & Sangat Efektif & \\
2017 & & $104,22 \%$ & Sangat Efektif & \\
2018 & \multirow{2}{*}{ Purworejo } & $47.74 \%$ & Tidak Efektif & \multirow{1}{*}{$161,67 \%$} \\
2019 & & $333,06 \%$ & Sangat Efektif & \\
\hline
\end{tabular}

Sumber: data diolah (2020)

Berdasarkan tabel 5 Kabupaten Kebemen memiliki tingkat efektivitas sebesar 165,07\% sedangkan Kabupaten Purworejo memiliki tingkat efektivitas sebesar 161,67\%.

Analisis Perbandingan Besar Kontribusi Penerimaan Pajak Reklame Terhadap Pendapatan Asli Daerah (PAD) Kabupaten Kebumen Dan Kabupaten Purworejo Tahun 2017-2019

Tabel 6 Perbandingan Besar Kontribusi pajak reklame Terhadap Pendapatan Asli Daerah di Kabupaten Kebumen dan Kabupaten Purworejo Tahun 2017-2019

\begin{tabular}{ccccc}
\hline Kabupaten & Tahun & Kontribusi & Kriteria Kontribusi & Rata-rata (\%) \\
\hline \multirow{3}{*}{ Kebumen } & 2017 & $0,14 \%$ & Relatif Tidak Berkontribusi & \\
& 2018 & $0,098 \%$ & Relatif Tidak Berkontribusi & $0,16 \%$ \\
& 2019 & $0,27 \%$ & Relatif Tidak Berkontribusi & \\
Purworejo & 2017 & $0,18 \%$ & Relatif Tidak Berkontribusi & \\
& 2018 & $0,09 \%$ & Relatif Tidak Berkontribusi & $0,20 \%$ \\
& 2019 & $0,35 \%$ & Relatif Tidak Berkontribusi & \\
\hline
\end{tabular}

Sumber: data diolah (2020)

Berdasarkan tabel 6 Kabupaten Kebemen memilik besar kontribusi sebesar

0,16\% sedangkan Kabupaten Purworejo memiliki tingkat efektivitas sebesar 0,20\%.

\section{PENUTUP}

Berdasarkan hasil penelitian dan pembahasan yang telah dilakukan, maka dapat ditarik simpulan sebagai berikut:

1. Tingkat efektifitas penerimaan pajak reklame di Kabupaten Kebumen dan Kabupaten Purworejo tahun 2017-2019 sudah sangat efektif karena rata-rata tingkat penerimaan pajak reklame lebih dari $100 \%$ 
2. Besar Kontribusi penerimaan pajak reklame terhadap Pendapatan Asli Daerah (PAD) di Kabupaten Kebumen dan Kabupaten Purworejo tahun 2017-2019 memiliki kriteria relatif tidak berkontribusi karena rata-rata tingkat kontribusi pajak reklame terhadap Pendaptan Asli Daerah (PAD) kurang dari 4\%

3. Perbandingan tingkat tingkat efektivitas pajak reklame Kabupaten Kebumen dan Kabupaten Purworejo tahun 2017-2019 pada tabel 9 dapat disimpulkan bahwa ratarata efektivitas pajak reklame Kabupaten Kebumen lebih unggul efektivitasnya dibandingkan dengan Kabupaten Purworejo.

4. Perbandingan besar kontribusi pajak reklame terhadap Pendapatan Asli Daerah (PAD) Kabupaten Kebumen dan Kabupaten Purworejo tahun 2017-2019 pada Tabel 10 dapat disimpulkan bahwa rata-rata besar kontribusi Kabupaten Purworejo lebih unggul besar kontribusinya dibandingkan dengan Kabupaten Kebumen.

Effectiveness of Regional

Advertisement Tax

\section{DAFTAR PUSTAKA}

Adiati, A. K., Diessela, P., \& Trisninik, R. W. 2017. Analisis Pajak Reklame di Kabupaten Purworejo Periode 2012-2016. Jurnal Akuntansi dan Pajak. Vol. 18. No. 01. Hal: 158-173.

Amyar, F., Hidayah, N. N., Lowe, A., \& Woods, M. (2019). Investigating the backstage of audit engagements: the paradox of team diversity. Accounting, Auditing \& Accountability Journal.

Anwar, A. D., \& Amyar, F. (2020). Analisis Faktor-Faktor Yang Mempengaruhi Kualitas Audit Internal Dalam Pengambilan Keputusan Laporan Keuangan Pada PT Damar Bandha Jaya Bogor. Jurnal Ilmiah Akuntansi Kesatuan, 8(1), 87-96.

Apriansyah, A., Pramiudi, U., \& Setiawan, H. (2019). Analisis Komparatif Perlakuan Akuntansi Atas Pendapatan Dan Beban. Jurnal Ilmiah Akuntansi Kesatuan, 7(1), 197-204.

Atteng, J., David, S., \& Lindya, M. 2016. Analisis Efektivitas dan Kontribusi Pajak Reklame Terhadap Pendapatan Asli Daerah (PAD) di Kota Manado Tahun 2011-2015. Jurnal Berkala Ilmiah Efisiensi. Vol. 16. No. 04. Hal: 4758.

Fauzi, R.C., Patriani, Y., Tiblola, J. and Munawar, A., 2020. Neo-Nepotism In Business Which Reducesthe Quality Of Democracy. European Journal of Molecular \& Clinical Medicine, 7(11), pp.1758-1763.

Febrina, M. R. 2018. Analisis Efektivitas dan Kontribusi Pajak Reklame Terhadap Pendapatan Asli Daerah (PAD) di Kabupaten Kebumen Tahun 20122016. Laporan Tugas Akhir. Hal: 1-57.

Halim, A. 2012. Pengelolaan Keuangan Daerah Edisi Ketiga. UUP STIM YKPN. Yogyakarta.

Harumdhani, N. 2012. Analisis Kontribusi dan Efektivitas Pajak Daerah Terhadap Penerimaan Pendapatan Asli Daerah (PAD) Kota Surakarta Tahun 2009-2011 (Perbedaan Atas Pelaksanaan UU No.34 Tahun 2000 Dan UU No.28 Tahun 2009 Tentang Pajak Daerah dan Retribusi Daerah). Sekripsi. Universitas Sebelas Maret. Surakarta.

Humaeni, A., Muanas, M., \& Sudradjat, S. (2019). Peranan Program Yongjin Erp Sebagai Sistem Informasi Akuntansi Pengendalian Persediaan Bahan Baku. Jurnal Ilmiah Akuntansi Kesatuan, 7(1), 213-218.

http://www.djpk.kemenku.go.id. Diakses pada 1 Oktober 2020. Pukul 12.51. http://kebumenkab.go.id. Diakses pada 22 Desember 2020. Pukul 10.21. http://purworejokab.go.id. Diakses pada 23 Desember 2020. Pukul 10.45. http://jateng.bps.go.id. Diakses pada 23 Desember 2020. Pukul 11.30. 
Effectiveness of Regional Advertisement Tax

214
Indriantoro, N., Supomo, B., \& Maya. 2018. Metodelogi Penelitian Bisnis: Untuk Akuntansi Dan Manajemen. Andi. Yogyakarta.

Lintong, A., Harijanto, S., \& Lidia, M. 2015. Analisis Perbandingan Kontribusi Pajak Reklame Kabupaten Minahasa Selatan dan Kabupaten Minahasa Terhadap Pajak Daerah. Jurnal EMBA. Vol. 3. No. 3. Hal: 441-450.

Mahmudi. 2010. Manajemen Kinerja Sektor Publik Edisi Dua. UPP STIM YKPN. Yogyakarta.

Mardiasmo. 2009. Akuntansi Sektor Publik. Andi. Yogyakarta. . 2013. Perpajakan Edisi Revisi. Andi. Yogyakarta.

Mulyana, M., 2012. Consumer Behaviour: Sukses Dengan Memahami Konsumen.

Purba, J.H.V., 2005. Strategi Diversifikasi Produk Terhadap Tingkat Omzet Penjualan (Studi Kasus pada PT. Surya Pelita Pratama). Jurnal Ilmiah Ranggagading, 5(1), pp.59-66.

Pratomo, A. 2018. Analisis Efektivitas dan Kontribusi Penerimaan Pajak Penerangan Jalan Terhadap Pendapatan Asli Daerah (PAD) Kabupaten Kebumen Tahun 2012-2016. Tugas Akhir. Hal: 12.

Prety, Hendrik, M., \& Treeseje, R. 2017. Analisis Perbandingan Kontribusi Pajak Daerah Terhadap Pendapatan Asli Daerah (PAD) di Kota Manado dan Kota Bitung Periode 2012-2016. Jurnal Riset Akuntansi Going Concern. Vol. 12. No.2. Hal: 432-431.

Rizka, A., Setiawan, S., \& Nur, C. 2020. Analisis Efektivitas dan Kontribusi Penerimaan Pajak Reklame Terhadap Pendapatan Asli Daerah Kabupaten Pekalongan . Balance: Economic, Business, Management, and Accounting Journal, Hal: 51-52.

Samudra, A. A. 2015. Perpajakan Di Indonesia: Keuangan, Pajak, Dan Retribusi Daerah. PT. Raja Grafindo Perseda. Jakarta.

Siahaan, M. P. 2010. Pajak Daerah dan Retribusi Daerah Berdasarkan UU No 28 Tahun 2009 tentang Pajak Daerah dan Retribusi Daerah. Rajawali Pres. Jakarta.

Siregar, B. 2017. Akuntansi Sektor Publik: Akuntansi Keuangan Pemerintah Daerah Berbasis Akrual Edisi Kedua. UPP STIM YKPN. Yogyakarta.

Sudradjat, S., \& Amyar, F. (2020). PKM Uji Kompetensi Bidang Keahlian Akuntansi di SMK Pembangunan Kota Bogor. Jurnal Abdimas Dedikasi Kesatuan, 1(1), 37-42.

Sugiono. 2018. Metode Penelitian Manejemen. Alfabeta. Bandung.

Undang-Undang Nonor 32 Tahun 2004 Pemerintah Daerah. Jakarta. Nomor 33 Tahun 2004 Perimbangan Keuangan Antara Pemerintah Pusat dan Daerah. Jakarta.

Nomor 28 Tahun 2009 Pajak Daerah dan Retribusi Daerah. Jakarta. Nomor 28 Tahun 2007 Perubahan ketiga Atas Undang-Undang Nomor 6 Tahun

1983 Tentang Ketentuan Umum dan Tata Cara Perpajakan. Jakarta. 